\title{
Characterization of Asphalt Binder Containing Microcapsules
}

\section{Mikrokapsüll içeren asfalt malzemelerin özelliklerinin Araștırıllması}

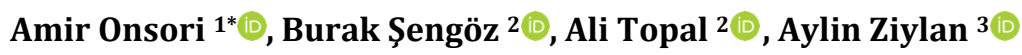 \\ ${ }^{1}$ Dokuz Eylül University The Graduate School of Natural and Applied Sciences, Izmir, TURKEY \\ 2 Dokuz Eylül University Faculty of Engineering Department of Civil Engineering, Izmir, TURKEY \\ ${ }^{3}$ Dokuz Eylül University Faculty of Engineerıng Department of Metallurgical and Materials Engineering, Izmir, TURKEY \\ Sorumlu Yazar / Corresponding Author*: a.onsori@gmail.com \\ DEUFMD, 23(67), 207-215.
}

\begin{abstract}
Asphalt pavements are exposed to traffic loading and adverse environmental effects such as rain and oxidation which result in decreasing their relaxation capabilities and the initiation of cracks. Recent research highlights the importance of developing long life pavements. One of the possible ways is to utilize innovative maintenance techniques such as self-healing technologies in order to reverse the aging process in asphalt binder. So as to achieve this goal, self-healing microcapsules seems to be an effective way to autonomously repair the micro-cracks, restore original mechanical properties, then further slow fatigue cracks growth and increase the fatigue life of the pavement.

In this study urea formaldehyde (UF) self-healing microcapsule were prepared by in-situ polymerization method. Following the characterization of microcapsules, different amount of microcapsules $(6,8,9,10,11$ and 12\%) were added into bitumen. Rheological properties of the samples have been determined by means of Dynamic Shear Rheometer. Ductility test was also employed to characterize the mechanical properties of the bitumen samples.

Based on results the produced microcapsules can endure high temperatures, which indicate that these microcapsules can resist the thermal influence of bitumen in application. Besides, bitumen samples involving microcapsules exhibit satisfactory results in terms of complex modulus $\left(G^{*}\right)$ and bitumen recovery tests. The recovery value of the modulus increased first and then decreased with the amount of microcapsules. Microcapsules containing rejuvenator will be a promising product to realize the smart pavements.
\end{abstract}

Keywords: Bitumen, Self-healing, Microencapsulation, Rejuvenator, In-situ polymerization

$\ddot{0} \mathbf{z}$

Asfalt kaplamalar, trafik yükleri, yağmur ve oksidasiyon gibi yol kaplamaları için olumsuz çevresel etkilerine maruz kalarak mekanik özelliklerini kaybetmektedir. Son zamanlardaki araștırmalar uzun ömürlü kaplamaların önemini vurgulamaktadır. Sürdürülebilirlik kapsamında bitümlü sıcak 
karışımlarının ömrünü korumak ve arttırabilmek amacı, asfalt endüstrisini farklı araştırmalara itmiş ve günümüzde "kendi kendini iyileştiren" (Self Healing) teknikler üzerine yoğunlaştırmıştır.

$\mathrm{Bu}$ hedefe ulaşmak için, kendi kendini onaran mikrokapsüller, mikro çatlakları otonom olarak onarmanın ve orijinal mekanik özellikleri geri kazanmanın, daha sonra mikro çatlaklarının büyümesini daha da yavaşlatmanın ve kaplamanın ömrünü uzatmanın etkili yöntemlerden biri olarak görünmektedir.

Bu çalışmada, üre ve formaldehit (UF) karışımı ile kendi kendini iyileştiren mikrokapsüller, in situ polimerizasyon yöntemi ile hazırlanmıştır. Mikro kapsüllerin karakterizasyon araştırılması ve asfalt içinde gösteren iyileşme oranını incelemek amacı ile bitüm içine farklı miktarda mikro kapsül $(6,8,9$ ,10, 11 ve \%12) eklenmiştir. Numunelerin reolojik özellikleri Dinamik Kesme Reometresi ile incelenmiștir. Ayrıca mikrokapsül içeren bitüm numunelerinin mekanik özelliklerinin tespiti için çekme testi yapılmıştır.

Üretilen mikro kapsüller uygulamada bitümün termal etkisine dayanabileceğini gösteren yüksek sıcaklıklara dayanabilmektedir. Ayrıca, mikro kapsülleri içeren bitüm numuneleri, kompleks modülü $\left(G{ }^{*}\right)$ ve bitümün mekanik özellikleri açısından tatmin edici sonuçlar göstermektedir. Araştırmaya göre İyileşme değeri ilk etapta artıyor ve bu mikrokapsüllerın asfalt malzemesinin mekanik özelliklerini geri kazanma göstergesidir. İyileştirici madde içeren mikro kapsüller, yeni nesil kaplamaları gerçekleştirmek için umut verici bir ürün olacaktır.

Anahtar Kelimeler: Bitüm, kendiliğinden iyileşen, mikro kapsül, iyileștirici madde, polimerizasiyon

\section{Introduction}

The global road network distances 16.3 million kilometers [1], of which 5 million kilometers is in the EU, 4.4 million kilometers in the USA and 3.1 million kilometers in China [2]. Road networks fulfill a major economic and social goal by facilitating the movement of goods and people. As a result, governments invest heavily in the development and maintenance of national and regional road networks. In 2009, EU governments invested $42 \%$ of the EU transport network fund into the development and maintenance of road networks. The development and maintenance of the global road network are crucial for the growth and competitiveness of the worldwide economy.

Recent research highlights indicate that a classic road system involves double or triple asphalt layers with an expected service life of 20-40 years. The aging of bitumen leads to pavement failure after years of utilization. The stiffness of asphalt materials increases while the relaxation capacity decreases, and the bitumen converts to more brittle materials as well as this issue resulting the progress of cracks and ultimately cracking of the interface between aggregates and bitumen $[3,4]$. The key cause of this phenomenon is the increment in the asphaltene/maltene ratio in bitumen. Under the combined action of traffic load, and environmental factors, micro cracks occur in the asphalt pavement. Then the micro cracks, with the continuous expansion and accumulation, expand into macroscopic cracks. If being not repaired in time, these cracks will affect the driving comfort and service life of pavement [5].

An increase in the application of a higher percentage of the preservation and renovation of asphalt pavement is achievable using a rejuvenator. The self-healing or self-repair material/system is considered to be the ability of the material to substantially return to the initial properties by making the necessary adjustments to restore to normality and the ability to resist the formation of irregularities and defects [6]. Self -healing asphalt pavement can detect and repair cracks by itself to some extent. In recent years, some procedures including microwave heating, induction heating, microcapsule and ion polymer and so on, have been used to heal the cracks in pavement. In other words, our ultimate aim is to develop an asphalt pavement material that will rejuvenate itself in the service life. In comparison with existing maintenance procedures, self-healing asphalt has the potential to improve traffic flow, reduce demand for fresh aggregate, reduce $\mathrm{CO}_{2}$ emissions and enhance road safety[7-11].

However, the use of rejuvenators presents a challenge as it is difficult to penetrate into the asphalt layer, which is necessary to rejuvenate the mix [12]. Therefore, encapsulation methods have been studied as an alternative in order to incorporate the use of rejuvenators into the mix 
during production[13]. The use of self-healing microencapsulation has been investigated to enhance the efficiency of self-healing processes [14]. Microcapsules may therefore break at different times during the bitumen aging history. The remaining microcapsules near the micro crack can then leak rejuvenator later when another micro crack is generated with an even higher crack tip strain. It has previously been reported that microcapsules containing rejuvenator can be fabricated with various shell thickness and size distributions [15-16]. The size and shell thickness are both important influencing factors of the micromechanical properties of the microcapsules. Firstly, the structure of microcapsules is taken into account for the specific requirement such as size distribution and encapsulation ratios; subsequently this affects their service performance.

In the light of the above information, the aim of this paper is to investigate the self-healing capability of bitumen including microcapsules filled with rejuvenator. Various samples were fabricated to investigate the healing performance of bituminous materials. Most of studies on the healing performance of microcapsule were more confined to evaluate the performance of microcapsule itself, but not the performance of asphalt containing microcapsule [16-17]. Therefore, for this purpose the bitumen tests focused on the bituminous material to evaluate the healing

Table 1. Properties of base bitumen performance of the asphalt. In order to observe the self-healing performance, ductility test under low temperature conditions and fatigue load tests was performed to spot the recovery properties. Virgin and rejuvenated bitumen properties were compared to evaluate the recovery behaviors of bituminous materials.

\section{Material and Method}

\subsection{Materials}

Self-healing microcapsules were prepared by insitu polymerization method [18]. Urea and formaldehyde (37\% aqueous) was used as the shell wall forming monomers which purchased from Merck KGaA Company . Polyvinyl alcohol (PVA) and Sodium dodecyl sulphate (SDS) which used as emulsifiers were procured from Acros Organics Company Bitumen rejuvenator which used as core material in microcapsules was prepared by mixing the lightweight organic oil containing high contents of aromatics.

Sodium hydroxide and citric acid were used for pH adjustment. The bitumen with a 50/70 penetration grade was procured from Aliaga/Izmir Oil Terminal of the Turkish Petroleum Refinery Corporation. In order to characterize the properties of the base bitumen, conventional test methods such as: penetration test and softening point test were performed. These tests were conducted in conformity with the relevant test methods that are presented in Table 1.

\begin{tabular}{llll}
\hline Test & Specification & Results & Specification limits \\
\hline Penetration $\left(25^{\circ} \mathrm{C} ; 0.1 \mathrm{~mm}\right)$ & ASTM D5 & 55 & $50-70$ \\
\hline Softening point $\left({ }^{\circ} \mathrm{C}\right)$ & ASTM D36 EN 1427 & 49.1 & $46-54$ \\
\hline Viscosity at $\left(135^{\circ} \mathrm{C}\right)$ Pa.s & ASTM D4402 & 0.413 & - \\
\hline TFOT $\left(163^{\circ} \mathrm{C} ; 5 \mathrm{~h}\right)$ & ASTM D1754 & 137.5 & - \\
\hline Change of mass $(\%)$ & & 0.04 & 50 (max) \\
\hline Retained penetration $(\%)$ & ASTM D5 EN 1426 & 51 & - \\
\hline Specific gravity & ASTM D70 & 1.030 & \\
\hline
\end{tabular}




\subsection{Core synthesis and preparation of microcapsules}

To prepare the microcapsules by in-situ polymerization method, first emulsion was created in $1000 \mathrm{ml}$ reactor. $600 \mathrm{ml}$ distilled water; $11 \mathrm{~g}$ emulsifier PVA and $2.5 \mathrm{~g}$ surfactant sodium dodecyl sulfate was added and thoroughly mixed. Pre-polymer was created to form the shell of the microcapsules. 18 gr urea reacts by $36 \mathrm{gr}$ formaldehyde at $55-65^{\circ} \mathrm{C}$ for $1 \mathrm{~h}$ in another container with adjusting the $\mathrm{PH}$ to 88.5 by using sodium hydroxide to obtain prepolymer. On the otherhand $15 \mathrm{gr}$ rejuvenator composed from organic oil prepared for using in core section. Reactor (containing the emulsion) Installation was prepared in a bath and the core solution added and mixed at $55-65^{\circ} \mathrm{C}$ for $30 \mathrm{~min}$. Then the pre-polymer added slowly and stirred at $250 \mathrm{rpm}$ and wait to reacting for $4 \mathrm{~h}$ while adjusting $\mathrm{pH}$ to 3 by using citric acid. The emulsion solution has been washed and filtered using water containing 10\% methanol then separated microcapsules have been dried in a vacuum oven at $30^{\circ} \mathrm{C}$ for $8 \mathrm{~h}$.

\subsection{Characterization of microcapsules}

\subsubsection{Morphology}

Morphology of the microcapsules was examined by scanning electron microscopy (SEM) using a Carl Zeiss 300VP microscope. The samples were vacuum dried and then mounted on aluminum stubs with double-stick tape. Then a layer of gold was evaporated onto the sample surface in a vacuum metallizing unit using QUORUM Q150.

\subsubsection{Chemical structure}

Attenuated Total Reflectance-Fourier Transform Infrared Spectroscopy (ATR-FTIR) (Perkin Elmer Spectrum BX) was used to determine the chemical structures of the microcapsules in the wave number range of $4000-500 \mathrm{~cm}^{-1}$ with the resolution of $4 \mathrm{~cm}^{-1}$ and 25 scans per sample to confirm that the microcapsules were filled with rejuvenator.

\subsection{Healing performance}

\subsubsection{Fatigue Test}

Asphalt fatigue test was performed to study healing performance under fatigue-load condition according to ASTM D7175-15. The test temperature was adjusted to $20{ }^{\circ} \mathrm{C}$, and stress control mode (0.3 $\mathrm{MPa})$ was adopted and the loading frequency was $10 \mathrm{~Hz}$. The loading process have divided into two stages: In the first load stage, the load stops until the modulus decreases to $60 \%$ of the initial modulus. A duration of $30 \mathrm{~min}$ is required for the bitumen to heal.After the end of heal stage, a second load stage begins, and the test finally ends till the modulus decrease to about $60 \%$ of the initial modulus again. A typical test result is shown in Fig. 1. Based on the variation of the modulus the healing indexes can be obtained by the following equations:

$$
\begin{aligned}
& \text { Healing index } 1=\frac{G_{\text {heal }}^{*}}{G_{\text {initial }}^{*}} \\
& \text { Healing index } 2(\mathrm{~Pa})=\left(G_{\text {heal }}^{*}-G_{\text {damage }}^{*}\right) 10^{6}
\end{aligned}
$$


DEÜ FMD 23(67), 207-215, 2021

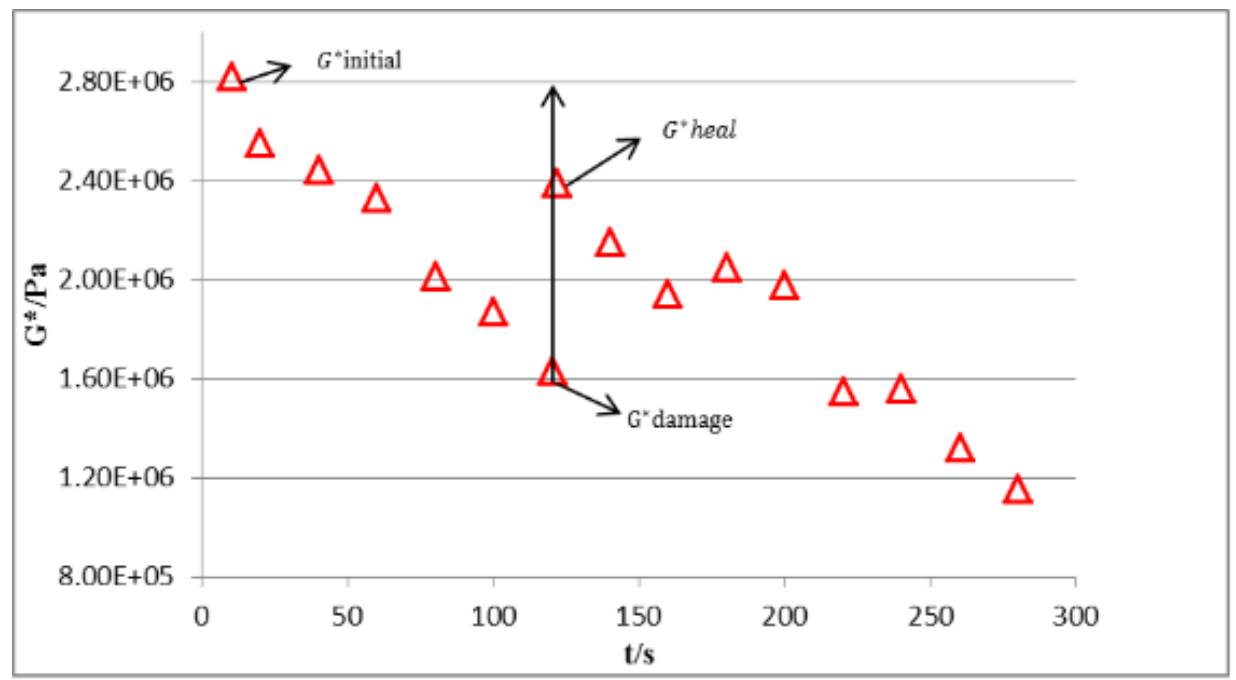

Figure 1 Typical fatigue load test consequences

\subsubsection{Ductility Test}

Ductility test was used to investigate the healing performance of microcapsules under low temperature condition according to ASTM D11307 . Test temperature was $5^{\circ} \mathrm{C}$ and tensile speed was adjusted at $1 \mathrm{~cm} / \mathrm{min}$. Before the test, the samples should have a pre-cut crack about $4 \mathrm{~mm}$ depth and then a 4 hour duration time is needed for the samples to heal [18] A typical procedure is presented in Fig. 2. The low-temperature healing efficiency (HE) can be expressed by following Equation:

$$
H E=\frac{L_{\text {Heal }}}{L_{\text {Original }}}
$$

Where HE is the healing efficiency, Lheal is the ductility of the sample with pre-cut crack after healing for 4 hours, and Loriginal is the ductility of intact sample.

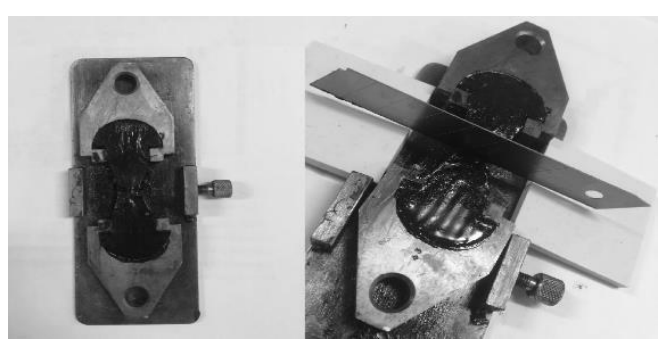

Figure 2. Preparation of sample for healing performance

\section{Results}

\subsection{Morphology}

Urea formaldehyde (UF) resin successfully applied to fabricate microcapsules containing rejuvenator by the in situ polymerization method. The shell thickness, surface morphology and average size of microcapsules were controlled by regulating the core/shell ratio, pre-polymer adding speed and emulsion stirring rate. The microcapsules were fabricated with a core/shell ratio of $1 / 2$ fabricated by 1500 r.min ${ }^{-}$ 1 emulsion stirring rates.

Fig. 3 shows the SEM micrograph of microcapsules. The surface of microcapsule is rough and scraggly, and it is composed of UF nanoparticles protruding from the surface. The protuberant nanoparticles can increase the surface areas of microcapsules and enhance surface adhesion. It is observed that the organic

core material is dispersed into particles in water and finally formed microcapsules with a mean sizes are about $100 \mu \mathrm{m}$. 


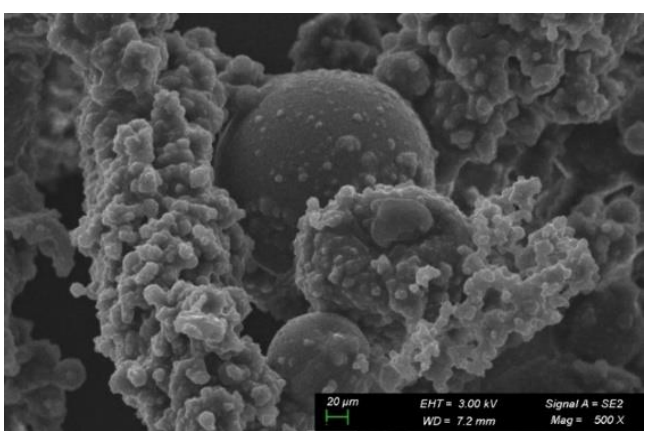

Figure 3. Morphology of microcapsules

\subsection{Chemical Structural characterization of microcapsules}

Fig. 4 presents the FTIR spectra of pre-polymer, a mixture of bitumen rejuvenator and UF core/shell material of microcapsules. As seen in Fig 4., the microcapsule has some different characteristic absorption peaks with bitumen rejuvenator, such as a vibration peak at $2917 \mathrm{~cm}^{-}$ 1 , an absorption peak at $1739 \mathrm{~cm}^{-1}$ and an absorption peak at $1176 \mathrm{~cm}^{-1}$. This indicates that the formation of the capsule shell has been established. In addition, some same characteristics peak with rejuvenator still exists, which fully verify that asphalt rejuvenator has been successfully covered by resin materials.

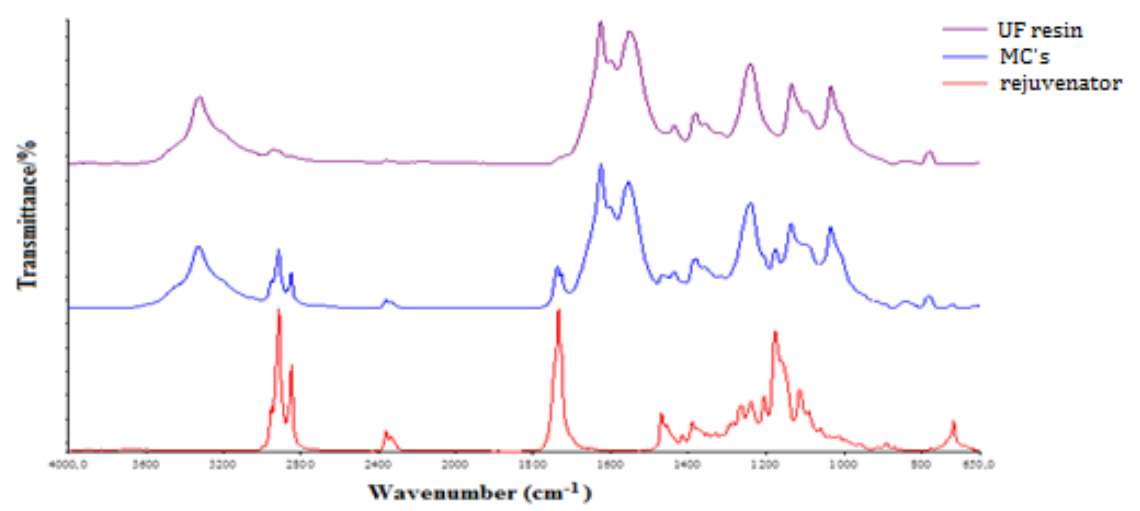

Figure 4. FTIR spectrogram of microcapsule and rejuvenator.

\subsection{Self-healing performance}

\subsubsection{Fatigue Test}

Dynamic shear rheometer was used to investigate the healing properties of the control sample and the bitumen samples involving different amount of microcapsules $(6,8,9,10,11$ and 12\%wt) Table 2 shows the healing performance of rejuvenator in bitumen under fatigue loading conditions.

As presented in Table 2 , the complex modulus of bitumen containing rejuvenator depicts

Table2. The healing performance (fatigue load) of asphalt with microcapsules

\begin{tabular}{|c|c|c|c|c|c|c|c|}
\hline \multirow{2}{*}{$\begin{array}{l}\text { Complex } \\
\text { Modulus }\end{array}$} & \multirow{2}{*}{$\begin{array}{l}\text { Control sample } \\
\text { (without microcapsule) }\end{array}$} & \multicolumn{6}{|c|}{ Bitumen sample involving microcapsule } \\
\hline & & $6 \%$ & $8 \%$ & $9 \%$ & $10 \%$ & $11 \%$ & $12 \%$ \\
\hline G*Initial & 2.002 & 2.1203 & 2.552 & 2.621 & 2.827 & 3.135 & 3.125 \\
\hline G"Damage & 1.135 & 1.194 & 1.5172 & 1.435 & 1.635 & 1.805 & 1.791 \\
\hline$G^{*}$ heal & 1.278 & 1.359 & 1.76972 & 1.923 & 2.394 & 2.491 & 2.427 \\
\hline
\end{tabular}

variation with the increment in the amount of microcapsules. Moreover, after healing for $0.5 \mathrm{~h}$, all asphalt samples containing different amounts of microcapsules displayed expected recovery performance. However, the recovery value of the modulus increased first and then decreased with the amount of microcapsules, and the asphalt containing $10 \%$ wt microcapsules had the maximum recovery value of $2.4 \mathrm{MPa}$, by contrast, the recovery value of control sample $(0 \%$ microcapsules) was $1.27 \mathrm{MPa}$. 
Figure 5 presents the results of healing indexes. Based on Fig.5, both of the calculated healing indexes increase with increase in the rate of microcapsule up to $10 \%$, however the index values depicts a decrease at 11 and $12 \%$ microcapsule \%.This indicates that $10 \% \mathrm{wt}$ microcapsules content yields the better recovery results against the other contents of rejuvenator.

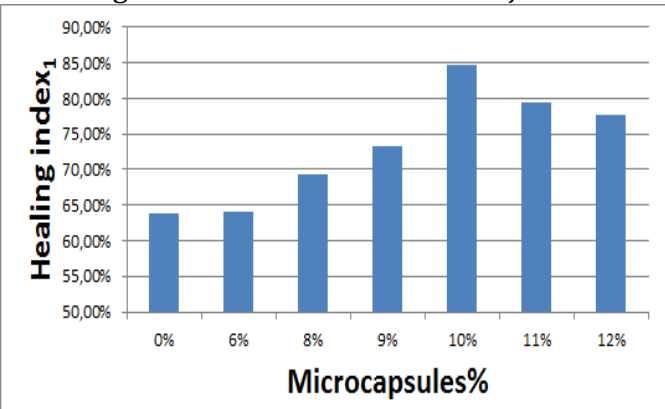

\subsubsection{Ductility Test}

Figure 5. Healing Indexes based in microcapsule rate

Ductility test was conducted with the $6,8,9,10$, 11 and 12 wt\% additive amount of microcapsules and also pure bitumen to investigate the self-healing performance of bitumen under low-temperature condition. As shown in Figure 6, the healing efficiency HE increased first and then decreased with the additive amount of microcapsules. The healing of ductility of asphalt.
An appropriate amount of microcapsules can effectively recover the flexibility of asphalt to improve the anti-fatigue performance of the bitumen; however excessive microcapsules will lead to the unnecessary flow deformation and bring in failings after the separation of capsules.

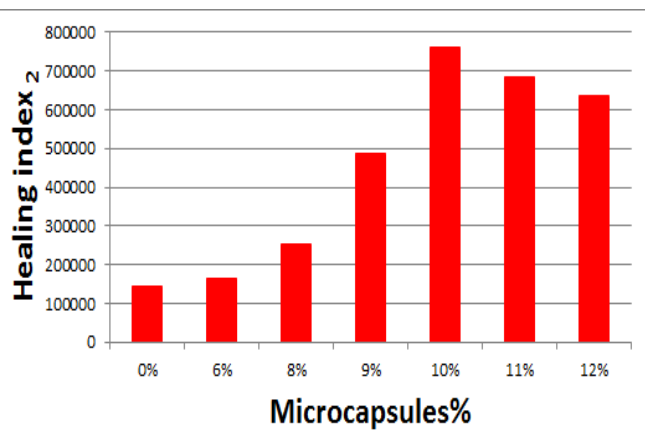

efficiency reached maximum as high as $84.25 \%$ when the additive amount of microcapsules was $10 \mathrm{wt} \%$ of the asphalt. The rejuvenator flowed out from the microcapsule to increase the liquidity of the asphalt, resulting in the increase of the ductility of asphalt. However, excessive microcapsule left too many holes in asphalt after the flow of rejuvenator, which led to the decrease

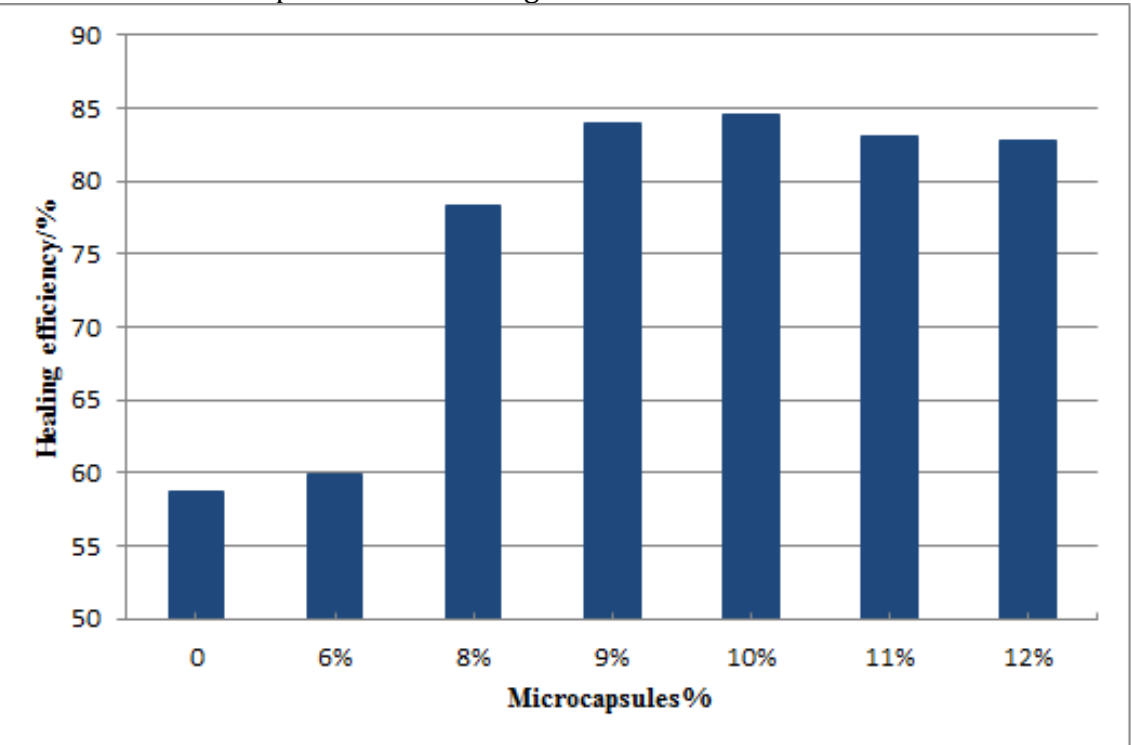

Figure 6. The healing performance of asphalt with microcapsules under low temperature conditions $\left(5^{\circ} \mathrm{C}\right)$. 


\section{DEÜ FMD 23(67), 207-215, 2021}

\section{Discussion and Conclusion}

The self-healing and recovery behaviors of bitumen containing microcapsules had been investigated by using fatigue test and low temperature ductility test. The obtained values had been documented to evaluate the recovery efficiency of rejuvenated bitumen. The structure of microcapsules had been investigated to understanding the healing procedure of bitumen. Based on the test results, the following conclusions can be drawn.

(1) Microcapsules containing oily rejuvenator were successfully fabricated. They could be dispersed in bitumen homogeneously. Oily rejuvenator can easily penetrate and diffuse into bitumen.

(2) The morphology and chemical structure characterization of microcapsules indicate that the microcapsules containing the functional groups of the capsule wall and the capsule core and the cores are successfully coated. The microcapsules are fairly stable and can withstand the procedure of preparation of asphalt pavement.

(3) Fatigue load test was used to investigate the healing performance of the bitumen with different amount of microcapsules. The complex modulus of bitumen containing rejuvenator presents variance with the amount of microcapsules. All samples containing microcapsules displayed expected recovery performance. The recovery value of the modulus increased first and then decreased with the amount of microcapsules, and the bitumen containing $10 \%$ wt microcapsules demonstrates the maximum recovery value.

(4) Recovery test indicated that the microcapsules had good healing efficiency for the bitumen under conditions of low temperature,. The healing efficiency increased up to $10 \%$ microcapsule rate; and then en a slight decrease is maintained above $10 \%$. It can be deduced that the optimal amount of microcapsules to show better performance was $10 \mathrm{wt} \%$ of the bitumen.

(5) The conclusion of this research covers the preparation of UF microcapsules filled with rejuvenator and charaterization of the mechanic properties of self healing asphalt. More research should carried out by using different test methods such as penetration, softening point,
IZOD impact strength test and creep test in order to perform more validation.

\section{Acknowledgement}

We would like to thank to Dokuz Eylül University Graduate School of Natural and Applied Sciences, editors and reviewers for their help to improve this manuscript.

\section{References}

[1] Organisation for Economic Cooperation and Development. 2013. Road traffic, vehicles and networks. In: Environment at a glance 2013: OECD indicators. OECD, Paris

[2] European Union Road Federation. 2012. European road statistics 2012. European Union Road Federation (ERF), Brussels.

[3] Qiu, J., Van de Ven, M.F.C., Wu, S., Yu, J., and Molenaar, A.A.A. 2009. Investigating the self-healing capability of bituminous binders, Road Mater. Pavement Design. Cilt. 10 s. 81-94. DOI: 10.1080/ 14680629. 2009.9690237

[4] Qiu, J., Van de Ven, M.F.C., Wu, S., Yu, J., and Molenaar, A.A.A. 2012. Evaluating self healing capability of bituminous mastics. Experimental Mechanics, cilt. 52, s. 1163-1171. DOI: 10.1007/s11340-011-9573-1

[5] B. Hilloulin, K. Van Tittelboom, E. Gruyaert, et al. 2013. Design of polymeric capsules for autonomous healing of cracks in cementitious materials. 4th International Conference on Self-Healing Materials

[6] A. Gonzalez, J. Norambuena-Contreras, L. Storey, et al. 2018. Effect of RAP and fibers addition on asphalt mixtures with self-healing properties gained by microwave radiation heating, Construction and Building Materials. Cilt. 159, s. 164-174. DOI: 10.1016/j.conbuildmat.2017.10.070

[7] Y.R. Kim, D. Little, R. Lytton. 2001. Evaluation of microdamage, healing, and heat dissipation of asphalt mixtures, using a dynamic mechanical analyzer, Transportation Research Record: Journal of the Transportation Research Board. Cilt. 1767, S. 60-66. DOI: 10.3141/1767-08

[8] T.P. Grant. 2001. Determination of Asphalt Mixture Healing Rate Using the Superpave Indirect Tensile Test. University of Florida. Yüksek lısans tezı, 82s, Florida.

[9] Dallas, N. Little, R.L. Lytton, B. Chairl, et al. 1999. An analysis of the mechanism of microdamage healing based on the application of micromechanics first principles of fracture and healing, Association of Asphalt Pavement Technologists.

[10] Amir Tabakovic', Dirk Braak, Mark van Gerwen, Oguzhan Copuroglu, Wouter Post, Santiago J. Garcia, Erik Schlangen. 2017. The compartmented alginate fibres optimisation for bitumen rejuvenator encapsulation. Journal of Traffic and Transportation Engineering. Cilt. 4, s. 347-359, https://doi.org/10.1016/j.jtte.2017.01.004

[11] Norambuena-Contreras Jose, Gonzalez-Torre Irene. 2017. Influence of the microwave heating time on the self-healing properties of asphalt mixtures, Applied

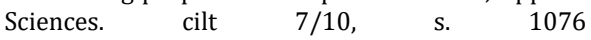
https://doi.org/10.3390/app7101076. 
[12] Chiu, C., and Lee, M. 2006. Effectiveness of seal rejuvenators for bituminous pavement surfaces, Journal of Testing and Evaluation. cilt 34, s.390394.DOI: 10.1520/JTE100056

[13] Garcia, A., Schlangen, E., Van de Ven M., and SierraBeltrán, G. 2010. Preparation of capsules containing rejuvenators for their use in asphalt concrete, Journal of Hazardous Materials. Cilt 184, S. 603-611. DOI: 501-542.1767-08.

[14] Aissa, B., Therriault, D., Haddad, E., and Jamroz, W. 2012. Self-healing materials systems: overview of major approaches and recent developed technologies, Advances in Material Science and $\begin{array}{llll}\text { Engineering. } & \text { Cilt } & 2012 . & \text { DOI: }\end{array}$ https://doi.org/10.1155/2012/854203

[15] Su, J.F., Qiu, J., and Schlangen, E. 2013. Stability investigation of self-healing microcapsules containing rejuvenator for bitumen, Polymer Degradation and Stability., cilt 98, S. 1205-1215 DOI: $10.1016 /$ j.polymdegradstab.2013.03.008

[16] Su, J.F., Schlangen, E. and Qiu, J. 2013. Design and construction of microcapsules containing rejuvenator for asphalt, Powder Technology. Cilt
235
563-571.
DOI:

https://doi.org/10.1016/j.powtec.2012.11.013

[17] Li, R., Zhou, T., Pei, J. 2015. Design, preparation and properties of microcapsules containing rejuvenator for asphalt, Construction and Building Materials. cilt 99,S. 143-149.

10.1016/j.conbuildmat.2015.09.017

[18] Sawada, K., and Urakawa, H. 2005. Preparation of photosensitive color-producing microcapsules utilizing in situ polymerization method, Dyes and $\begin{array}{llll}\text { Pigments.cilt } & 65, & \text { s. } & 45-49 . \\ \end{array}$ 10.1016/j.dyepig.2004.06.021 